\title{
Role of p38 Signaling Pathway in Pentagastrin-Regulated Cell Proliferation of Colorectal Carcinoma Cell Line HT-29
}

\author{
Jiading Mao, Pei Wu, Jian Wu, Liang Tao, Ping Wu, Guang Yang, Wenwen Guo, Jun Wang \\ Department of General Surgery, The First Affiliated Yijishan Hospital of Wannan Medical College, Wuhu, China \\ Email: maojiading0205@sina.com
}

Received 30 April 2016; accepted 11 June 2016; published 14 June 2016

Copyright $@ 2016$ by authors and Scientific Research Publishing Inc. This work is licensed under the Creative Commons Attribution International License (CC BY). http://creativecommons.org/licenses/by/4.0/ c) (i) Open Access

\section{Abstract}

Objective: To investigate the effects and mechanisms of p38 signaling pathway in pentagastrinregulated cell proliferation of colorectal carcinoma cell line HT-29. Methods: HT-29 cell line of colorectal carcinoma was in vitro incubated and divided into the control group, pentagastrin group, proglumide group, and pentagastrin + proglumide group. MTT reduction assay was performed to detect the proliferation status of HT-29 cell line and determine the optimal dosage of pentagastrin and proglumide. Annexin V-fluorescein isothiocyanate flow cytometry was used to detect the proliferation index (PI) and apoptosis rate (AR) of HT-29 cells. Reverse transcriptase polymerase chain reaction was performed to detect the mRNA expression of the pentagastrin receptor/cholecystokinin-B receptor (CCK-BR) and p38. The protein and phosphorylation levels of p38 were estimated by western blotting. Results: RT-PCR detection showed that CCK-BR mRNA was expressed in the HT-29 cell line. Pentagatrin improved HT-29 cell proliferation in dosage of 6.25 $100 \mathrm{mg} / \mathrm{L}$, and the optimal dosage of pentagastrin was $25.0 \mathrm{mg} / \mathrm{L}$. Proglumide had no significant effect on the proliferation of HT-29 cells, but significantly inhibited the proliferation of HT-29 cells stimulated by pentagastrin when the dosage of proglumide was $8.0-128.0 \mathrm{mg} / \mathrm{L}$, and the optimal dosage was $32.0 \mathrm{mg} / \mathrm{L}$. The AR in the pentagastrin group was significantly lower than that in the control group and in the pentagastrin + proglumide group. The PI in the pentagastrin group was significantly higher than that in the control group and in the pentagastrin + proglumide group. P38 phosphorylation level in the pentagastrin group was significantly lower than that in the control group, and in the pentagastrin + proglumide group. There were no significant differences in the mRNA and protein expression of $\mathrm{p} 38$ in the control, pentagastrin, proglumide and pentagastrin + proglumide groups. Conclusion: Pentagastrin can improve proliferation of the CRC cell line HT-29 and inhibit apoptosis via the p38 signal transduction pathway. This mechanism may be associated with suppressed $\mathbf{p} 38$ protein phosphorylation level due to inhibition of proglumide, a ga- 


\section{strin receptor antagonist.}

\section{Keywords}

\section{Gastrin, p38, Proglumide, Proliferation Index, Apoptosis Rate, MAPK, Colorectal Carcinoma}

\section{Introduction}

Colorectal carcinoma (CRC) is one of the most common malignant tumors of the human digestive tract, and is the second to third leading cause of gastrointestinal cancer-related mortality worldwide [1]-[5]. In developed countries such as Australia, North America, New Zealand and parts of Europe, CRC is considered to be a disease of western lifestyle, and has an incidence of 35 - 50/10 million people/year. In China, the incidence and mortality of colon cancer now rank third and fifth, respectively [6]-[9]. Incidence rates are more than 30/10 million people/year. In recent years, there has been a trend towards an increase in the incidence of CRC in China. Although major progress has been made in understanding the molecular mechanisms of CRC and several therapeutic agents have been developed, it is still difficult to cure, poses a serious threat to human health, and remains as a major killer in China. The overall 5-year survival rate of patients with CRC is approximately 60\% [9]. Therefore, it is crucial to identify which cytokines regulate the growth of CRC so as to elucidate the etiology of these tumors. In addition, determining the mechanisms of uncontrollable tumor cell growth in light of signal transduction pathways could help identify a new method of treating these malignant tumors.

Previous studies have shown that the occurrence of CRC is directly related to the abnormal expression of gastrin [10]-[15]. In addition, some studies have found that gastrin promotes growth and inhibits apoptosis of CRC cells. However, the detailed molecular mechanism of gastrin-regulated growth of CRC cells is still unclear. We used the MTT assay to detect changes in the proliferation of HT-29 cells; annexin V-fluorescein isothiocyanate (FITC) flow cytometry to determine the proliferation index (PI) and apoptosis rate (AR) of HT-29 cells; reverse transcriptase polymerase chain reaction (RT-PCR) to detect expression of the pentagastrin receptor/cholecystokinin-B receptor (CCK-BR) and p38; and western blotting to detect the protein and phosphorylation level of p38. The purpose of the present study was to determine the effects and mechanisms of the p38 signal transduction pathway in pentagastrin-induced proliferation and apoptosis of CRC cells.

\section{Materials and Methods}

\subsection{Materials and Reagents}

Pentagastrin was purchased from Shanghai Tian Yuan Biotechnology Co., Ltd. (Shanghai, China). Proglumide and the propidium iodide staining kit were purchased from Sigma (St. Louis, MO, United States). P38 rabbit polyclonal anti-human antibody, phosphorylated p38 rabbit anti-human polyclonal antibody, b-actin antibody, and the ECL chromogenic detection kit were purchased from Santa Cruz Biotechnology (Santa Cruz, CA, United States). The human CRC cell line HT-29 was purchased from Shanghai Institutes for Biological Sciences, Chinese Academy of Sciences, China. The Annexin V-EGFP/PI apoptosis detection kit was purchased from Mbchem (Shanghai, China). The reverse transcription kit, SK312 Trizol reagent, Taq DNA polymerase, DNA marker, and dNTP were purchased from Promega (Madison, WI, United States). The gastrin receptor/CCK-BR, p38 and muscle b-actin mRNA amplification primers were synthesized by Beijing Sunbiotech Co., Ltd. (Beijing, China).

\subsection{Cell Lines Culture and Grouping Type}

Cells were subcultured when the cells reached $80 \%$ confluence in Corning $50 \mathrm{~cm}$ cell culture flasks (Corning, Madison, WI, United States) containing 10\% fetal calf serum in RPMI-1640. Resuscitated cells with a high cell density were subjected to timely passage, generally 2 - $3 \mathrm{~d}$ for a new generation. Cells in the logarithmic growth phase after digestion and centrifugation with removal of digestive fluid and culture medium underwent cryopreservation in $\mathrm{a}-70^{\circ} \mathrm{C}$ liquid nitrogen tank for later use. The cells were divided into four groups: control group, pentagastrin group, proglumide group, and pentagastrin + proglumide group. 


\subsection{Optimal Experimental Dose of Gastrin and Proglumid Assay}

HT-29 cells in the logarithmic growth phase, were digested into a single cell suspension in $10 \%$ fetal bovine serum (FBS) medium, and the cell concentration was adjusted to $5 \times 10^{4}$ cells $/ \mathrm{mL}$. The cells were seeded in 96-well culture plates (each well contained $200 \mathrm{~mL}$ ) and cultured for $24 \mathrm{~h}$. The culture medium was discarded when the cells were adherent. After washing with D-Hank's solution, serum-free medium was added and the cells were cultured for $24 \mathrm{~h}$. FBS medium $(100 \mathrm{~mL}$, 1\%) was added to each well, along with $100 \mathrm{~mL}$ of each drug. In the pentagastrin group, the pentagastrin concentration was $6.25,12.5,25.0,50.0$ or $100.0 \mathrm{mg} / \mathrm{L}$. In the proglumide group, the proglumide concentration was $8.0,16.0,32.0,64.0$ or $128.0 \mathrm{mg} / \mathrm{L}$. In the pentagastrin + proglumide group, the pentagastrin concentration was $25.0 \mathrm{mg} / \mathrm{L}$ and the proglumide concentration was 8.0, 16.0, 32.0, 64.0 or $128.0 \mathrm{mg} / \mathrm{L}$. No drugs were added to the control group. Each treatment group consisting of six wells was cultured for $48 \mathrm{~h}$. For the MTT method, MTT $(5 \mathrm{mg} / \mathrm{mL})$ was added to each well of the 96-well plate, and incubated at $37^{\circ} \mathrm{C}$ for $4 \mathrm{~h}$. The culture medium was then discarded and $150 \mathrm{~mL}$ DMSO was added to each well, and the plate was then shaken for $10 \mathrm{~min}$ at room temperature. OD492 was measured by ELISA, and the results of the six wells in each group are presented as mean \pm SD and the experiments were repeated three times.

\subsection{Cell Proliferation and Apoptosis Assay}

Cells in the logarithmic growth phase were digested with $0.25 \%$ trypsin and adjusted to a concentration of $1.7 \times$ $10^{5}$ cells/mL in 10\% FBS medium in six-well plates ( $2 \mathrm{~mL} /$ well). After $24 \mathrm{~h}$, FBS medium was replaced with serum-free medium, and the cells were cultured for a further $24 \mathrm{~h}$ to absorb the supernatant. Then, $1 \mathrm{~mL} 1 \%$ FBS medium was added to each well, along with $1 \mathrm{~mL}$ of the following: pentagastrin group $(25.0 \mathrm{mg} / \mathrm{L}$ pentagastrin); proglumide group (32.0 mg/L proglumide); pentagastrin + proglumide group ( $25.0 \mathrm{mg} / \mathrm{L}$ pentagastrin + $32.0 \mathrm{mg} / \mathrm{L}$ proglumide); control group (no drugs). Each group consisted of five wells, and the cells were cultured for $48 \mathrm{~h}$. After digestion with $0.25 \%$ trypsin, the cells were centrifuged at $12,000 \times \mathrm{g}$ at $4^{\circ} \mathrm{C}$ for $10 \mathrm{~min}$, and the supernatant was discarded. One milliliter of cold PBS was added, and the cell suspension was gently shaken. The supernatant was discarded after centrifugation at $12,000 \times \mathrm{g}$ at $4^{\circ} \mathrm{C}$ for $10 \mathrm{~min}$. After washing twice with cold PBS, the cells were resuspended in $200 \mathrm{~mL}$ binding buffer, fixed with $1 \mathrm{~mL} 70 \%$ ethanol, DNA and protein stained, and the proportion and the PI of the cell cycle were determined by flow cytometry.

After $48 \mathrm{~h}$ incubation with or without drugs, the cells were collected from the control, pentagastrin (25.0 $\mathrm{mg} / \mathrm{L})$, proglumide $(32.0 \mathrm{mg} / \mathrm{L})$, and proglumide $(25.0 \mathrm{mg} / \mathrm{L})+$ pentagastrin $(32.0 \mathrm{mg} / \mathrm{L})$ groups, and adjusted to a concentration of $2 \times 10^{6} / \mathrm{mL}$. One milliliter of cells was taken from each group, and centrifuged at $12,000 \times \mathrm{g}$ at $4^{\circ} \mathrm{C}$ for $10 \mathrm{~min}$, and the supernatant was discarded. One milliliter of cold PBS was added to resuspend the cells, which was then shaken gently. The cell suspension was centrifuged again at $12,000 \times \mathrm{g}$ at $4^{\circ} \mathrm{C}$ for $10 \mathrm{~min}$. The supernatant was removed, the cells were washed twice with cold PBS, and then resuspended in $200 \mathrm{~mL}$ binding buffer. We added $10 \mathrm{~mL}$ Annexin V-FITC and $5 \mathrm{~mL}$ propidium iodide, and mixed gently in the dark at room temperature for $15 \mathrm{~min}$. Then, $300 \mathrm{~mL}$ binding buffer was added, and cell AR was determined one hour later.

\subsection{CCK-BR and p38 mRNA Assay}

Total RNA extraction and cDNA synthesis were performed as described previously [16]. mRNA expression of CCK-BR and p38 was detected by RT-PCR. The primer sequences are listed in Table 1, and the specific steps were carried out according to the kit instructions (Promega, Madison, WI, United States). The mean optical density (OD) values of the amplified product bands were determined by Tanon gel imaging and Image System version 4.0. The results were expressed as the semi-quantitative density ratio of the samples such as CCK-BR, p38 and b-actin.

\subsection{Western Blot Assay}

The protein expression and phosphorylation level of p38 were detected by Western blotting. The specific steps were carried out according to the kit instructions. The primary antibody was diluted with Tris-buffered saline and Tween to a concentration of 1:500, and treated with electrophoresis, transfer film and ECL development. Gel Image System software was used to determine the average OD. The results were expressed as the relative ratios of the target gene expression, respectively, and b-actin expression. 
Table 1. Primers used for nested reverse transcriptase polymerase chain reaction amplification of cholecystokinin-B receptor and p38.

\begin{tabular}{|c|c|c|c|}
\hline Name & Primer sequence & PCR conditions & Size (bp) \\
\hline \multirow[t]{3}{*}{ CCK-BR } & 1: 5’TCTCGCGAGCTCTACTTAGGG3’ & $94^{\circ} \mathrm{C}, 30 \mathrm{~s}$ & 185 \\
\hline & 2: 5’ACCGACGATGCACGTTGAAG3' & $62^{\circ} \mathrm{C}, 30 \mathrm{~s}$ & \\
\hline & & $72^{\circ} \mathrm{C}, 30 \mathrm{~s}$ & \\
\hline \multirow[t]{3}{*}{ P38 } & 1: 5’GTGCCCGAGCGTTACCAGAA3' & $94^{\circ} \mathrm{C}, 30 \mathrm{~s}$ & 266 \\
\hline & 2: 5’GTGCCGAGCCAGTCCAAAATC3' & $56^{\circ} \mathrm{C}, 30 \mathrm{~s}$ & \\
\hline & & $72^{\circ} \mathrm{C}, 30 \mathrm{~s}$ & \\
\hline \multirow[t]{3}{*}{ Actin } & 1: 5’ATGATATCGCCGCGCTCGTCGTC3' & $94^{\circ} \mathrm{C}, 30 \mathrm{~s}$ & 342 \\
\hline & 2: 5’CGCGGTTGGCCTTGGGGTTCAG3' & $60^{\circ} \mathrm{C}, 30 \mathrm{~s}$ & \\
\hline & & $72^{\circ} \mathrm{C}, 30 \mathrm{~s}$ & \\
\hline
\end{tabular}

PCR: Polymerase chain reaction; CCK-BR: Cholecystokinin-B receptor.

\subsection{Statistical Analysis}

Statistical evaluation was performed using the Student-Newman-Keul Q test, and the data are shown as mean \pm standard deviation (mean $\pm \mathrm{SD}$ ); all data were analyzed using SPSS 13.0 software. $P<0.05$ was considered statistically significant.

\section{Results}

\subsection{The Effect of Different Dose of Gastrin and Proglumid on Cell Proliferation}

The MTT assay showed that pentagastrin stimulated the proliferation of HT-29 cells and inhibited apoptosis in a dose-dependent manner $(6.25$ - $100 \mathrm{mg} / \mathrm{L})$, and the optimal dose was $25 \mathrm{mg} / \mathrm{L}(P<0.05)$. As the pentagastrin concentration continued to increase, OD did not increase. Proglumide had no obvious effect on HT-29 cell proliferation at a dose range of $8.0-128.0 \mathrm{mg} / \mathrm{L}(P>0.05)$. However, proglumide markedly inhibited pentagastrininduced proliferation of CRC cells when pentagastrin was at the optimal dose of $25 \mathrm{mg} / \mathrm{L}$. When the proglumide concentration was $32.00 \mathrm{mg} / \mathrm{L}$ or greater, the active cell number in the pentagastrin + proglumide group tended to be constant and the optimal dose of proglumide was $32 \mathrm{mg} / \mathrm{L}(P<0.05)$ (Table 2 and Table 3).

\subsection{Comparison of Cell Proliferation Index and Apoptosis Rate among All Groups}

The results showed that the PI in the pentagastrin group was significantly higher than that in the other experimental groups, while the AR was significantly decreased $(P<0.01)$. In the pentagastrin group, the PI was 37.5\% $\pm 5.2 \%$, which was significantly higher than that in the control $(27.7 \% \pm 5.0 \%)$ and pentagastrin + proglumide $(27.3 \% \pm 5.8 \%)$ groups $(P<0.05)$. In the proglumide group, the PI was $27.4 \% \pm 2.7 \%$, which did not differ significantly from the control group $(P>0.05)$. In the pentagastrin group, the AR was $1.9 \% \pm 0.4 \%$, which was significantly lower than that in the control $(2.5 \% \pm 0.4 \%)(P<0.05)$ and pentagastrin + proglumide $(2.4 \% \pm$ $0.3 \%)(P<0.05)$ groups. In the proglumide group, the AR was $2.8 \% \pm 0.5 \%$, which did not differ significantly from the control group $(P>0.05)$.

\subsection{Expression of CCK-BR in HT-29 Cells and Comparison of p38 mRNA among All Groups}

RT-PCR showed that CCK-BR mRNA was expressed in HT-29 cells. The amplification products of CCK-BR, p38 and b-actin mRNA were 185, 266 and 342 bp, respectively. There was no obvious change in the expression of p38 mRNA in the control, pentagastrin, proglumide and pentagastrin + proglumide groups $(P>0.05)$ (Table 4, Figure 1 and Figure 2). 
Table 2. Effects of different pentagastrin and proglumide concentrations on the proliferation of HT-29 cells (mean \pm SD).

\begin{tabular}{cccccc}
\hline \multirow{2}{*}{ Groups } & & \multicolumn{2}{c}{ Pentagastrin } & \multicolumn{2}{c}{ Proglumide } \\
\cline { 3 - 6 } & & Concentration $(\mathrm{mg} / \mathrm{L})$ & OD value & Concentration $(\mathrm{mg} / \mathrm{L})$ & OD value \\
\hline Control group & 6 & 0 & $0.44 \pm 0.00$ & 0 & $0.44 \pm 0.02$ \\
Experimental group & 6 & 6.25 & $0.48 \pm 0.03^{\mathrm{a}}$ & 8 & $0.43 \pm 0.03$ \\
& 6 & 12.5 & $0.52 \pm 0.03^{\mathrm{a}}$ & 16 & $0.44 \pm 0.04$ \\
& 6 & 25 & $0.57 \pm 0.04^{\mathrm{a}}$ & 32 & $0.43 \pm 0.03$ \\
& 6 & 50 & $0.58 \pm 0.04^{\mathrm{a}}$ & 64 & $0.45 \pm 0.02$ \\
\hline
\end{tabular}

${ }^{\mathrm{a}} \mathrm{P}<0.05$ vs control group. OD: optical density.

Table 3. Effects of combined pentagastrin and proglumide on the proliferation of HT-29 cells (mean $\pm \mathrm{SD}$ ).

\begin{tabular}{ccccc}
\hline \multirow{2}{*}{ Groups } & $n$ & \multicolumn{3}{c}{ Pentagastrin + proglumide } \\
\cline { 3 - 5 } & & Pentagastrin $(\mathrm{mg} / \mathrm{L})$ & Proglumide $(\mathrm{mg} / \mathrm{L})$ & OD value \\
\hline Control group & 6 & 25 & 0 & $0.58 \pm 0.02$ \\
Experimental group & 6 & 25 & 8 & $0.54 \pm 0.03^{\mathrm{a}}$ \\
& 6 & 25 & 16 & $0.51 \pm 0.04^{\mathrm{a}}$ \\
& 6 & 25 & 32 & $0.47 \pm 0.04^{\mathrm{a}}$ \\
& 6 & 25 & 64 & $0.47 \pm 0.03^{\mathrm{a}}$ \\
& 6 & 25 & 128 & $0.46 \pm 0.03^{\mathrm{a}}$ \\
\hline
\end{tabular}

${ }^{\mathrm{a}} \mathrm{P}<0.05$ vs control group. OD: optical density.

Table 4. Comparison of protein, mRNA and phosphorylation levels of p38 between the experimental groups (mean $\pm \mathrm{SD}$ ) and control group.

\begin{tabular}{ccccc}
\hline Group & & & p38 & \\
\cline { 3 - 5 } & $n$ & mRNA & Protein & p-p38 \\
Control group & 5 & $0.57 \pm 0.04$ & $0.88 \pm 0.04$ & $0.75 \pm 0.06$ \\
Pentagastrin group & 5 & $0.58 \pm 0.04$ & $0.83 \pm 0.06$ & $0.64 \pm 0.05^{\mathrm{a}}$ \\
Proglumide group & 5 & $0.56 \pm 0.05$ & $0.84 \pm 0.05$ & $0.76 \pm 0.06^{\mathrm{c}}$ \\
Pentagastrin + proglumide group & 5 & $0.58 \pm 0.05$ & $0.87 \pm 0.05$ & $0.81 \pm 0.05^{\mathrm{c}}$ \\
\hline
\end{tabular}

${ }^{\mathrm{a}} \mathrm{P}<0.05$ vs control group; ${ }^{\mathrm{C}} \mathrm{P}<0.05$ vs pentagastrin group.

\subsection{Protein Expression and Phosphorylation Levels of p38 among All Groups}

Following incubation of HT-29 cells with the drugs for $72 \mathrm{~h}, \mathrm{p} 38$ phosphorylation level in the pentagastrin group was $0.64 \% \pm 0.05 \%$, which was significantly lower than that in the control group $(0.75 \% \pm 0.06 \%)(P<$ $0.05)$, and the pentagastrin + proglumide group $(0.81 \% \pm 0.05 \%)(P<0.05)$. There were no significant differences in the protein expression of p38 among the control $(0.88 \% \pm 0.04 \%)$, pentagastrin $(0.83 \% \pm 0.06 \%)$, proglumide $(0.84 \% \pm 0.05 \%)$ and pentagastrin + proglumide groups $(0.87 \% \pm 0.05 \%)(P>0.05)$. There was no significant difference in the protein phosphorylation level of p38 between the proglumide $(32 \mathrm{mg} / \mathrm{L})$ and control groups $(P>0.05)$ (Table 4, Figure 3$)$. 


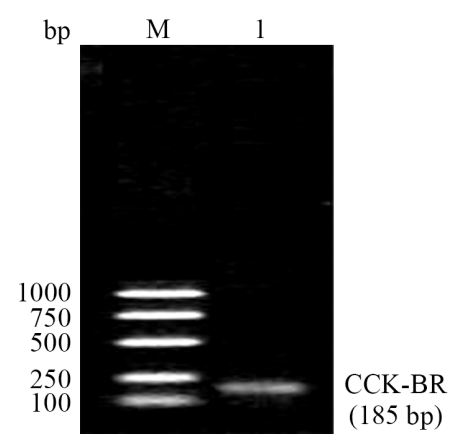

Figure 1. Analysis of CCK-BR mRNA expression in HT-29 cells by nested reverse transcriptase polymerase chain reaction. Lane M: DNA marker; lane 1: CCK-BR.

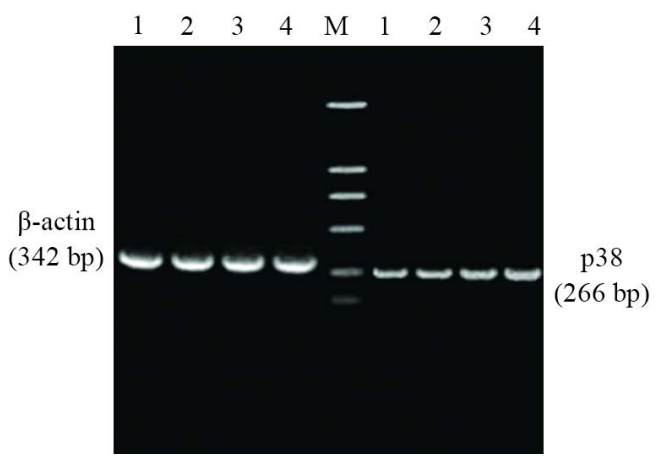

Figure 2. Analysis of p38 and b-actin mRNA expression in HT-29 cells by nested reverse transcriptase polymerase chain reaction. Lane M: DNA marker; lane 1: control group; lane 2: pentagastrin group; lane 3: proglumide group; lane 4: pentagastrin + proglumide group.

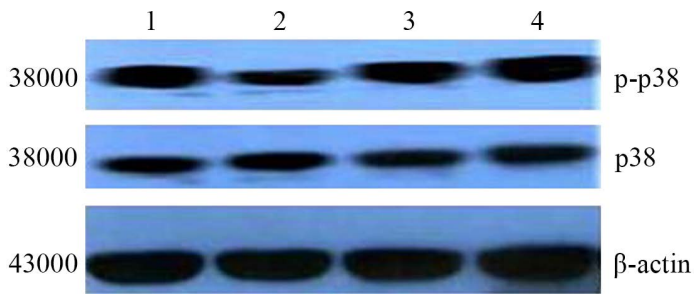

Figure 3. Analysis of p38 and p-p38 protein expression in each experimental group by western blotting. lane 1 : control group; lane 2: pentagastrin group; lane 3: proglumide group; lane 4: pentagastrin + proglumide group.

\section{Discussion}

Gastrin was discovered as early as 1905 in the extracts of gastric antral mucosa and is associated with gastric acid secretion. In 1964, it was isolated and identified by Gregory and Tracy who determined its chemical structure and confirmed it as a gastrointestinal hormone [17] [18]. The peptide hormone gastrin stimulates gastric acid secretion, and is an important growth factor in the gastric mucosa. Gastrin is an important polypeptide gastrointestinal hormone that is mainly secreted by gastrointestinal G cells in the digestive tract. It is the central regulator of gastric acid secretion, but also regulates growth and differentiation of pancreatic, gallbladder, gastric and CRC and other tumor cells [19]-[21]. Recent studies have shown that gastrin is an autocrine growth factor that exerts its function through autocrine, paracrine and endocrine modes [20] [22] [23]. The combination 
of gastrin and its receptor can regulate tumor cell growth by intracellular signaling transduction pathways, and can exert biological effects [24] [25]. Most studies have demonstrated that the incidence of CRC is related to abnormal expression of gastrin. Some researchers have referred to this type of CRC as a hormone-dependent tumor, which promotes cell proliferation through the generation and secretion of gastrin, which acts on its own receptor located on the cell membrane to exert a biological effect, but its effects can be inhibited by gastrin receptor antagonists [26] [27].

The results of the present study show that the concentration gradient of gastrin within a certain dose range promoted HT-29 cell proliferation and inhibited apoptosis. As the concentration increased from $25 \mathrm{mg} / \mathrm{L}$, proliferation did not continue to increase, which was consistent with the receptor saturation theory. It was clear that the number of gastrin receptors and their affinity determined the strength of the effects on CRC cells. We also found that gastrin promoted the proliferation of HT-29 cells and inhibited apoptosis by accelerating the S and G2 phases of the cell cycle. The gastrin-promoted CRC cell proliferation and inhibition of apoptosis were inhibited by the gastrin receptor antagonist proglumide. In addition, our study also showed that there was no significant impact on the CRC cell cycle when only proglumide was added. When pentagastrin was combined with proglumide, PI decreased and AR increased, although these did not differ significantly from the control group. Proglumide markedly inhibited pentagastrin-induced proliferation of large intestinal cancer cells in a dose-dependent manner within a certain range, and the optimal dose was $32 \mathrm{mg} / \mathrm{L}$, which is also in line with the receptor saturation theory. Gastrin can promote cell proliferation in human CRC and inhibit apoptosis [13] [28]-[33]. However, the molecular mechanism involved in the regulation of CRC growth remains unclear.

In recent years, gene chip technology has been used to detect CRC-related gene expression. Studies have shown that many CRC-related genes are closely associated with the activation and inhibition of signal transduction pathways in many internal and external networks, and are directly involved in cell proliferation, differentiation and apoptosis [34]-[36]. P38 is an important intracellular signal transduction molecule, and is a member of the MAPK family. During cell proliferation, differentiation, development and apoptosis, it plays an important regulatory role [37] [38]. Mammalian cells express 4 subgroups of p38, namely p38 alpha (p38 $\alpha$ ), p38 beta (p38 $\beta$ ), p38 gamma (p38 $\gamma$ ) and p38 delta (p38 $\delta$ ) [39] [40]. Many studies have suggested that the p38 signaling pathway is involved in the regulation of CRC cell growth [41]-[43]. The p38 signal transduction pathway plays an important role in gastrin-regulated proliferation and apoptosis of CRC cells [44] [45]. In general, phosphorylation is a molecular switch in signal transduction pathways, which controls protein activity in different pathways, such as metabolism, signal transduction, cell division, and other aspects. Thus, through phosphorylation, it can be established whether the signaling pathway is activated, and the strength of the activation. Our results indicated that pentagastrin significantly downregulated the protein phosphorylation level of p38. Proglumide alone had no significant effect on the level of p38 phosphorylation in HT-29 cells, but when combined with pentagastrin, proglumide significantly antagonized the role of pentagastrin, and the protein phosphorylation levels of p38 were significantly upregulated in HT-29 cells. However, there were no significant differences in the mRNA and protein expression of p38 among the different groups. Our results indicate that gastrin promoted the proliferation of human CRC cells and inhibited apoptosis, and these effects were inhibited by the gastrin receptor antagonist proglumide. Gastrin may regulate the proliferation and apoptosis of CRC cells via the p38 signaling pathway, and reduce the protein phosphorylation level of p38.

\section{Conclusion}

In summary, gastrin promotes the proliferation of human CRC HT-29 cells and inhibits apoptosis, but these effects are inhibited by the gastrin receptor antagonist proglumide. The p38-MAPK signaling transduction pathway is involved in gastrin-regulated proliferation and apoptosis of CRC cells. However, which target genes are involved in this mechanism under the downstream signaling transduction pathway requires in-depth study. In addition, we expect to identify a new treatment strategy for gastrin-dependent CRC if we can competitively inhibit the gastrin receptors or increase the p38 phosphorylation levels of the p38-MAPK signaling pathway.

\section{Acknowledgements}

This study was supported by the Natural Science Foundation of Anhui Province (1408085MH148) and Talent Introduction Science Fund of Yijishan Hospital (YR201406), and Natural Science Fund of Wannan Medical College (WK2012zf02). 


\section{References}

[1] Shin, H.R., Carlos, M.C. and Varghese, C. (2012) Cancer Control in the Asia Pacific Region: Current Status and Concerns. Japanese Journal of Clinical Oncology, 42, 867-881. http://dx.doi.org/10.1093/jjco/hys077

[2] Mihajlović, J., Pechlivanoglou, P., Miladinov-Mikov, M., Zivković, S. and Postma, M.J. (2013) Cancer Incidence and Mortality in Serbia 1999-2009. BMC Cancer, 13, 18. http://dx.doi.org/10.1186/1471-2407-13-18

[3] Aranda-Hernández, J., Hwang, J. and Kandel, G. (2016) Seeing Better-Evidence Based Recommendations on Optimizing Colonoscopy Adenoma Detection Rate. World Journal of Gastroenterology, 22, 1767-1778. http://dx.doi.org/10.3748/wjg.v22.i5.1767

[4] Ballester, V., Rashtak, S. and Boardman, L. (2016) Clinical and Molecular Features of Young-Onset Colorectal Cancer. World Journal of Gastroenterology, 22, 1736-1744. http://dx.doi.org/10.3748/wjg.v22.i5.1736

[5] Gomez, S.L., Noone, A.M., Lichtensztajn, D.Y., Scoppa, S., Gibson, J.T., Liu, L., Morris, C., Kwong, S., Fish, K., Wilkens, L.R., Goodman, M.T., Deapen, D. and Miller, B.A. (2013) Cancer Incidence Trends among Asian American Populations in the United States, 1990-2008. Journal of the National Cancer Institute, 105, 1096-1110. http://dx.doi.org/10.1093/jnci/djt157

[6] Wang, X., Song, Z.F., Xie, R.M., Pei, J., Xiang, M.F. and Wang, H. (2013) Analysis of Death Causes of In-Patients with Malignant Tumors in Sichuan Cancer Hospital of China from 2002 to 2012. Asian Pacific Organization for Cancer Prevention, 14, 4399-4402. http://dx.doi.org/10.7314/APJCP.2013.14.7.4399

[7] Chen, W., Zheng, R., Zhang, S., Zhao, P., Li, G., Wu, L. and He, J. (2013) Report of Incidence and Mortality in China Cancer Registries, 2009. Chinese Journal of Cancer Research, 25, 10-21.

[8] Li, J., Chang, J., Zhu, Y., Yang, Y., Gong, Y., Ke, J., Lou, J., Zhong, R., Gong, J., Xia, X. and Miao, X. (2015) Risk Prediction of Colorectal Cancer with Common Genetic Variants and Conventional Non-Genetic Factors in a Chinese Han population. Zhonghua Liu Xing Bing Xue Za Zhi, 36, 1053-1057.

[9] Yao, H., Shu, C., Hu, S. and Liu, Y. (2016) Future Diagnosis and Treatment of Colorectal Cancer from the View of Precision Medicine. Zhonghua Wei Chang Wai Ke Za Zhi, 19, 7-12.

[10] Najib, S., Kowalski-Chauvel, A., Do, C., Roche, S., Cohen-Jonathan-Moyal, E. and Seva, C. (2015) Progastrin a New Pro-Angiogenic Factor in Colorectal Cancer. Oncogene, 34, 3120-3130. http://dx.doi.org/10.1038/onc.2014.255

[11] Paterson, A.C., Macrae, F.A., Pizzey, C., Baldwin, G.S. and Shulkes, A. (2014) Circulating Gastrin Concentrations in Patients at Increased Risk of Developing Colorectal Carcinoma. Journal of Gastroenterology and Hepatology, 29, 480486. http://dx.doi.org/10.1111/jgh.12417

[12] Westwood, D.A., Patel, O. and Baldwin, G.S. (2013) Gastrin Mediates Resistance to Hypoxia-Induced Cell Death in Xenografts of the Human Colorectal Cancer Cell Line LoVo. Biochimica et Biophysica Acta, 1843, 2471-2480. http://dx.doi.org/10.1016/j.bbamcr.2014.06.016

[13] Mao, J.D., Wu, P., Huang, J.X., Wu, J. and Yang, G. (2014) Role of ERK-MAPK Signaling Pathway in PentagastrinRegulated Growth of Large Intestinal Carcinoma. World Journal of Gastroenterology, 20, 12542-12550. http://dx.doi.org/10.3748/wjg.v20.i35.12542

[14] Chueca, E., Lanas, A. and Piazuelo, E. (2012) Role of Gastrin-Peptides in Barrett's and Colorectal Carcinogenesis. World Journal of Gastroenterology, 18, 6560-6570. http://dx.doi.org/10.3748/wjg.v18.i45.6560

[15] Chao, C. and Hellmich, M.R. (2010) Gastrin, Inflammation, and Carcinogenesis. Current Opinion in Endocrinology, Diabetes and Obesity, 17, 33-39.

[16] Kreeger, P.K., Mandhana, R., Alford, S.K., Haigis, K.M. and Lauffenburger, D.A. (2009) RAS Mutations Affect Tumor Necrosis Factor-Induced Apoptosis in Colon Carcinoma Cells via ERK-Modulatory Negative and Positive Feedback Circuits along with Non-ERK Pathway Effects. Cancer Research, 69, 8191-8199. http://dx.doi.org/10.1158/0008-5472.CAN-09-1921

[17] Modlin, I.M., Kidd, M., Marks, I.N. and Tang, L.H. (1997) The Pivotal Role of John S. Edkins in the Discovery of Gastrin. World Journal of Surgery, 21, 226-234. http://dx.doi.org/10.1007/s002689900221

[18] Gregory, R.A. and Tracy, H.J. (1964) The Constitution and Properties of Two Gastrins Extracted from Hog Antral Mucosa. Gut, 5, 103-114. http://dx.doi.org/10.1136/gut.5.2.103

[19] Steigedal, T.S., Prestvik, W.S., Selvik, L.K., Fjeldbo, C.S., Bruland, T., Lægreid, A. and Thommesen, L. (2013) Gastrin-Induced Proliferation Involves MEK Partner 1 (MP1). In Vitro Cellular \& Developmental Biology—Animal, 49, 162-169. http://dx.doi.org/10.1007/s11626-013-9588-2

[20] Tripathi, S., Flobak, A., Chawla, K., Baudot, A., Bruland, T., Thommesen, L., Kuiper, M. and Lægreid, A. (2015) The Gastrin and Cholecystokinin Receptors Mediated Signaling Network: A Scaffold for Data Analysis and New Hypotheses on Regulatory Mechanisms. BMC Systems Biology, 9, 40. http://dx.doi.org/10.1186/s12918-015-0181-Z

[21] Xu, W., Chen, G.S., Shao, Y., Li, X.L., Xu, H.C., Zhang, H., Zhu, G.Q., Zhou, Y.C., He, X.P. and Sun, W.H. (2013) 
Gastrin Acting on the Cholecystokinin2 Receptor Induces Cyclooxygenase-2 Expression through JAK2/STAT3/PI3K/ Akt Pathway in Human Gastric Cancer Cells. Cancer Letters, 332, 11-18. http://dx.doi.org/10.1016/j.canlet.2012.12.030

[22] Sellam, F., Harir, N., Khaled, M.B., Mrabent, N.M., Belkralladi, H., Tou, A., Diaf, M., Salah, R. and Moulessehoul, S. (2015) Immunohistochemical Examination of Cholecystokinin and Gastrin Receptors (CCK-2/Gastrin-R) Expression in Normal and Exocrine Cancerous Human Pancreatic Tissues. Pancreatology, 15, 661-666. http://dx.doi.org/10.1016/j.pan.2015.09.019

[23] Hayakawa, Y., Jin, G., Wang, H., Chen, X., Westphalen, C.B., Asfaha, S., Renz, B.W., Ariyama, H., Dubeykovskaya, Z.A., Takemoto, Y., Lee, Y., Muley, A., Tailor, Y., Chen, D., Muthupalani, S., Fox, J.G., Shulkes, A., Worthley, D.L., Takaishi, S. and Wang, T.C. (2015) CCK2R Identifies and Regulates Gastric Antral Stem Cell States and Carcinogenesis. Gut, 64, 544-553. http://dx.doi.org/10.1136/gutjnl-2014-307190

[24] Cui, Y., Li, S.B., Peng, X.C., Wu, J. and Fu, G.H. (2015) Trastuzumab Inhibits Growth of HER2-Negative Gastric Cancer Cells through Gastrin-Initialized CCKBR Signaling. Digestive Diseases and Sciences, 60, 3631-3641. http://dx.doi.org/10.1007/s10620-015-3793-7

[25] Patel, M., Kawano, T., Suzuki, N., Hamakubo, T., Karginov, A.V. and Kozasa, T. (2014) G $\alpha_{13} /$ PDZ-RhoGEF/RhoA Signaling Is Essential for Gastrin-Releasing Peptide Receptor-Mediated Colon Cancer Cell Migration. Molecular Pharmacology, 86, 252-262. http://dx.doi.org/10.1124/mol.114.093914

[26] Song, Y., Xu, Y., Wang, Z., Chen, Y., Yue, Z., Gao, P., Xing, C. and Xu, H. (2012) MicroRNA-148b Suppresses Cell Growth by Targeting Cholecystokinin-2 Receptor in Colorectal Cancer. International Journal of Cancer, 131, 10421051. http://dx.doi.org/10.1002/ijc.26485

[27] Jin, G., Westphalen, C.B., Hayakawa, Y., Worthley, D.L., Asfaha, S., Yang, X., Chen, X., Si, Y., Wang, H., Tailor, Y., Friedman, R.A. and Wang, T.C. (2013) Progastrin Stimulates Colonic Cell Proliferation via CCK2R- and $\beta$-ArrestinDependent Suppression of BMP2. Gastroenterology, 145, 820-830. http://dx.doi.org/10.1053/j.gastro.2013.07.034

[28] Wu, P., Mao, J.D., Yan, J.Y., Rui, J., Zhao, Y.C., Li, X.H. and Xu, G.Q. (2005) Correlation between the Expressions of Gastrin, Somatostatin and Cyclin and Cyclin-Depend Kinase in Colorectal Cancer. World Journal of Gastroenterology, 11, 7211-7217. http://dx.doi.org/10.3748/wjg.v11.i45.7211

[29] Huang, B.P., Lin, C.H., Chen, Y.C. and Kao, S.H. (2015) Expression of Cholecystokinin Receptors in Colon Cancer and the Clinical Correlation in Taiwan. Tumor Biology, 37, 4579-4584. http://dx.doi.org/10.1007/s13277-015-4306-1

[30] Mao, J.D., Wu, P., Yang, Y.L., Wu, J. and Huang, H. (2008) Relationship between Expression of Gastrin, Somatostatin, Fas/FasL and Caspases in Large Intestinal Carcinoma. World Journal of Gastroenterology, 14, 2802-2809. http://dx.doi.org/10.3748/wjg.14.2802

[31] Han, Y.M., Park, J.M., Kangwan, N., Jeong, M., Lee, S., Cho, J.Y., Ko, W.J. and Hahm, K.B. (2015) Role of Proton Pump Inhibitors in Preventing Hypergastrinemia-Associated Carcinogenesis and in Antagonizing the Trophic Effect of Gastrin. Journal of Physiology and Pharmacology, 66, 159-167.

[32] Mao, J.D., Wu, P., Xia, X.H., Hu, J.Q., Huang, W.B. and Xu, G.Q. (2005) Correlation between Expression of Gastrin, Somatostatin and Cell Apoptosis Regulation Gene Bcl-2/Bax in Large Intestine Carcinoma. World Journal of Gastroenterology, 11, 721-725. http://dx.doi.org/10.3748/wjg.v11.i5.721

[33] Wu, P., Mao, J.D., Zhao, Y.C., Wu, J. and Huang, H. (2010) Relationship between the Cells Proliferation of Large Intestinal Cancer Induced by Gastrin and Signaling Transduction Pathway of STAT3. International Journal of Surgery, 37, 243-247.

[34] Zalata, K.R., Elshal, M.F., Foda, A.A. and Shoma, A. (2015) Genetic Dissimilarity between Primary Colorectal Carcinomas and Their Lymph Node Metastases: Ploidy, p53, Bcl-2, and c-Myc Expression-A Pilot Study. Tumor Biology, 36, 6579-6584. http://dx.doi.org/10.1007/s13277-015-3353-y

[35] Mansour, M.A., Hyodo, T., Ito, S., Kurita, K., Kokuryo, T., Uehara, K., Nagino, M., Takahashi, M., Hamaguchi, M. and Senga, T. (2015) SATB2 Suppresses the Progression of Colorectal Cancer Cells via Inactivation of MEK5/ERK5 Signaling. The FEBS Journal, 282, 1394-1405. http://dx.doi.org/10.1111/febs.13227

[36] Wang, B., Shen, Z.L., Gao, Z.D., Zhao, G., Wang, C.Y., Yang, Y., Zhang, J.Z., Yan, Y.C., Shen, C., Jiang, K.W., Ye, Y.J. and Wang, S. (2015) MiR-194, Commonly Repressed in Colorectal Cancer, Suppresses Tumor Growth by Regulating the MAP4K4/c-Jun/MDM2 Signaling Pathway. Cell Cycle, 14, 1046-1058. http://dx.doi.org/10.1080/15384101.2015.1007767

[37] Huseby, N.E., Ravuri, C. and Moens, U. (2016) The Proteasome Inhibitor Lactacystin Enhances GSH Synthesis Capacity by Increased Expression of Antioxidant Components in an Nrf2-Independent, but p38 MAPK-Dependent Manner in Rat Colorectal Carcinoma Cells. Free Radical Research, 50, 1-13. http://dx.doi.org/10.3109/10715762.2015.1100730

[38] Xiang, T., Fei, R., Wang, Z., Shen, Z., Qian, J. and Chen, W. (2016) Nicotine Enhances Invasion and Metastasis of 
Human Colorectal Cancer Cells through the Nicotinic Acetylcholine Receptor Downstream p38 MAPK Signaling Pathway. Oncology Reports, 35, 205-210.

[39] Del Reino, P., Alsina-Beauchamp, D., Escós, A., Cerezo-Guisado, M.I., Risco, A., Aparicio, N., Zur, R., FernandezEstévez, M., Collantes, E., Montans, J. and Cuenda, A. (2014) Pro-Oncogenic Role of Alternative p38 Mitogen-Activated Protein Kinases p38 $\gamma$ and p38 $\delta$, Linking Inflammation and Cancer in Colitis-Associated Colon Cancer. Cancer Research, 74, 6150-6160. http://dx.doi.org/10.1158/0008-5472.CAN-14-0870

[40] Ramachandra, C.J., Mehta, A., Wong, P. and Shim, W. (2016) ErbB4 Activated p38y MAPK Isoform Mediates Early Cardiogenesis through NKx2.5 in Human Pluripotent Stem Cells. Stem Cells, 34, 288-298. http://dx.doi.org/10.1002/stem.2223

[41] Wang, J., Huang, F., Bai, Z., Chi, B., Wu, J. and Chen, X. (2015) Curcumol Inhibits Growth and Induces Apoptosis of Colorectal Cancer LoVo Cell Line via IGF-1R and p38 MAPK Pathway. International Journal of Molecular Sciences, 16, 19851-19867. http://dx.doi.org/10.3390/ijms160819851

[42] Song, H.M., Park, G.H., Eo, H.J., Lee, J.W., Kim, M.K., Lee, J.R., Lee, M.H., Koo, J.S. and Jeong, J.B. (2015) AntiProliferative Effect of Naringenin through p38-Dependent Downregulation of Cyclin D1 in Human Colorectal Cancer Cells. Biomolecules \& Therapeutics (Seoul), 23, 339-344. http://dx.doi.org/10.4062/biomolther.2015.024

[43] Ren, H., Zhang, S., Ma, H., Wang, Y., Liu, D., Wang, X. and Wang, Z. (2014) Matrine Reduces the Proliferation and Invasion of Colorectal Cancer Cells via Reducing the Activity of p38 Signaling Pathway. Acta Biochimica et Biophysica Sinica, 46, 1049-1055. http://dx.doi.org/10.1093/abbs/gmu101

[44] Ming, M., Yu, J.P., Zhou, Y.H., Cao, J., Song, W.C., Yu, H.G. and Luo, H.S. (2007) The Role of p38 MAPK in Gastrin-Induced U-PA Expression in Human Colon Cancer Cells. Chinese Journal of Oncology, 29, 4-8.

[45] Han, Y.M., Hahm, K.B., Park, J.M., Hong, S.P. and Kim, E.H. (2013) Paradoxically Augmented Anti-Tumorigenic Action of Proton Pump Inhibitor and Gastrinin APC ${ }^{\text {Min/+ }}$ Intestinal Polyposis Model1. Neoplasia, 16, 73-83.

http://dx.doi.org/10.1593/neo.131510

\section{Submit or recommend next manuscript to SCIRP and we will provide best service for you:}

Accepting pre-submission inquiries through Email, Facebook, Linkedin, Twitter, etc A wide selection of journals (inclusive of 9 subjects, more than 200 journals)

Providing a 24-hour high-quality service

User-friendly online submission system

Fair and swift peer-review system

Efficient typesetting and proofreading procedure

Display of the result of downloads and visits, as well as the number of cited articles

Maximum dissemination of your research work

Submit your manuscript at: http://papersubmission.scirp.org/ 